\title{
A Case Study of Social and Corporate Responsibility in Bridging the Digital Divide
}

\author{
Tom Butler \\ University College Cork, Ireland.
}

tbutter@afis.ucc.ie

\begin{abstract}
Being on the wrong side of the digital divide limits the life chances of the socially excluded, who have had neither the wherewithal nor the opportunity to obtain highly paid, skilled positions in IT. Irish policy makers see education as the solution to this problem. However, providing institutional support for third level education in IT for the socially disadvantaged poses significant challenges. This paper describes these problems and explains how they were overcome in implementing an undergraduate university course. This diploma course has been an unqualified success has achieved its objectives and those of the policy makers who instituted it. However, what made it so was the commitment of concerned stakeholders, from members of the executive steering committee who developed and implemented the course, to the lecturers who delivered it, and the students who participated in it.
\end{abstract}

Keywords: Digital Divide, Commitment, Education, IT

\section{Introduction}

In the information age, being on the wrong side of the digital divide can limit significantly a person's life chances. This is particularly true of the socially excluded in Ireland, who have had neither the wherewithal nor the opportunity to obtain highly paid, skilled positions in the IT sector. As such, they are observers rather than participants in the Celtic Tiger economy. On the other side of the divide, the national and multinational firms on which Ireland's thriving economy depends are starved of skilled IT professionals. In 1999, this situation became critical as Ireland was reaching full employment. At the time, the universities and third level institutions were not turning out enough qualified graduates to meet the growing demand. Worse still, bright school leavers from working class backgrounds were being attracted by the high pay and conditions on offer in the manufacturing and service industries. Then there were those who, due to their social circumstances and life chances, failed to enter third level education or who were underemployed or long-term unemployed. This gap between supply and demand required innovative solutions as the problems confronting the Irish Government, its various agencies, industry, and third level institutions were novel. This case study identifies these problems and reveals how one initiative was successful in providing a solution that met the needs of government, industry, third level institutions, and the socially excluded. On a theoretical note, this study's analysis of findings is based on a grounded theory approach (Lincoln \& Guba, 1985); however, theoretical insights from institutional sociology are introduced to help understand and explain the findings. The following section introduces Philip Selznick's

Material published as part of these proceedings, either on-line or in print, is copyrighted by Informing Science. Permission to make digital or paper copy of part or all of these works for personal or classroom use is granted without fee provided that the copies are not made or distributed for profit or commercial advantage AND that copies 1) bear this notice in full and 2) give the full citation on the first page. It is permissible to abstract these works so long as credit is given. To copy in all other cases or to republish or to post on a server or to redistribute to lists requires specific permission from the publisher at Publisher@intormingscience.org
$(1949,1957)$ theory of commitment and examines the role of commitment in shaping institutions; $\mathrm{Sec}-$ tion 3 then outlines the research approach adopted for this study. The case report is presented in Section 4, while the final section discusses and analyses the findings and offers several conclusions. 


\section{Commitment and the Social Construction of Institutions}

In his study of the Tennessee Valley Authority, Philip Selznick (1949) examined the institutional forces surrounding the development and implementation of a government-sponsored initiative. Here, Selznick described how an organization's character is socially constructed through the commitments entered into by social actors. He later refined this theory in his seminal research on organizational leadership. In brief, Selznick's (1949, pp. 258-259) theory posits that:

The systematized commitments of an organization define its character. Day-to-day decision, relevant to the actual problems met in the translation of policy into action, create precedents, alliances, effective symbols, and personal loyalties which transform the organization from a profane, maniputable instrument into something having a sacred status and thus resistant to treatment simply as a means to some external goal.

Thus, when organizations are conditioned by the patterned, responsive interaction of committed individuals and groups, their formal systems - which are described as the technical, rational, impersonal and taskoriented component of organizations - are transformed, over time, into adaptive social structures. Support for Selznick's position is to be found in the cultural psychology of Jerome Bruner (1990) who argued that social actors establish their value systems by committing to 'ways of life' and that the complex interactions of individual 'ways of life' in turn constitute a culture. As with Selznick, Bruner provides a good example of the reciprocal link between the character of societies and institutional groupings and those of the individuals who constitute them.

Selznick (1949) delineates several types of commitment; these are illustrated in Table 1. Here, 'commitment' refers to the binding of an individual to particular behavioural acts in the pursuit of organizational objectives. While Selznick (1949) employs the term 'enforced' to indicate the mechanisms by which

\begin{tabular}{|l|l|}
\hline Type of Commitment & Description \\
\hline $\begin{array}{l}\text { Commitments enforced by } \\
\text { uniquely organizational im- } \\
\text { peratives. [OI] }\end{array}$ & $\begin{array}{l}\text { Organizational imperatives are concerned with 'reality' maintenance. They are } \\
\text { usually implemented by policy decisions associated with system maintenance; } \\
\text { consequently, they ensure that the organizational requirements of order, disci- } \\
\text { pline, unity, defense, and consent are fulfilled. }\end{array}$ \\
\hline $\begin{array}{l}\text { Commitments enforced by } \\
\text { the social character of the } \\
\text { personnel. [SCP] }\end{array}$ & $\begin{array}{l}\text { The personnel, or so-called human capital, in organizations come to an organi- } \\
\text { zation with particular needs, levels of aspiration, training and education, social } \\
\text { ideals and class interest; thus, influences from the external environment are di- } \\
\text { rectly imported into an organization by its personnel. }\end{array}$ \\
\hline $\begin{array}{l}\text { Commitments enforced by } \\
\text { institutionalization. [I] }\end{array}$ & $\begin{array}{l}\text { Because organizations are social systems, goals, policies or procedures tend to } \\
\text { achieve an established, value-impregnated status. Commitment to established or } \\
\text { institutionalized patterns is thereby accomplished, restricting choice and enforc- } \\
\text { ing specific behavioural standards. }\end{array}$ \\
\hline $\begin{array}{l}\text { Commitments enforced by } \\
\text { the social and cultural envi- } \\
\text { ronment. [SCE] }\end{array}$ & $\begin{array}{l}\text { Organizational policies and outcomes are often influenced and shaped by actors } \\
\text { in the external social and cultural environment. }\end{array}$ \\
\hline $\begin{array}{l}\text { Commitments enforced by } \\
\text { the centers of interest gener- } \\
\text { ated in the course of action. } \\
\text { [CIGCA] }\end{array}$ & $\begin{array}{l}\text { Decentralization and delegation of decision making to particular individuals and } \\
\text { groups within an organization runs the risk that policies and programs, influ- } \\
\text { enced by the tangential informal goals of these individuals and sectional inter- } \\
\text { ests, and which are unanticipated and incongruent with those of the organiza- } \\
\text { tion, will be entered into. }\end{array}$ \\
\hline
\end{tabular}

Table 1: Commitment as the Determinant of Organizational character (adapted from Selznick, 1949)

(A coding scheme is employed to designate the type of commitment described. This scheme is used in the case report to indicate where and how the commitments entered into by institutional actors socially constructed the institutional context that underpinned the successful implementation of the Diploma in Applied Business Computing.) 
'commitment' is operationalized in organizational contexts, enforcement does not necessarily imply that social actors are at all times compelled regulative forces to adopt desired behavioural patterns in the pursuance of organizational objectives. Winograd \& Flores (1986), for example, argue that the 'speech acts' of actors in socially constructed contexts give rise to the various commitments there observed. Bruner (1990) too focuses on 'speech acts' and emphasizes the role of narrative in the construction and maintenance of social worlds. In addition, it is clear from Selznick that the locus of commitment and its 'enforcement' varies from the individual in certain circumstances, to social groupings, to the organization of which they are members, and to agencies outside the organization. Thus, as Scott (1995) has illustrated, normative and cognitive mechanisms are also at play. Scott (1995) therefore argues that institutions are multifaceted in nature, encompass symbolic systems - constituted by the cognitive constructions of social actors and the normative rules and constraints they operate under-and involve the application of regulative processes which are shaped by and in turn influence participating social actors. Thus, the chief strength of Selznick's $(1949,1957)$ work is that it spans the normative, cognitive and regulative perspectives on institutions; hence, in DiMaggio \& Powell's (1991) schema, it can help uncover the 'normative' [NOR], 'mimetic' [MI], and 'coercive' [COR] influences that shape institutions.

\section{Research Approach}

This study of the institutional processes around the exercise of social and corporate responsibility is interpretive and case-based. The qualitative and inductive nature of case-based research is noted by Walsham \& Waema (1994): they argue that the use of a single case study as a basis for drawing inferences about a particular area of study is related to an interpretive epistemological stance. Orlikowski \& Baroudi (1991) also maintain that a case-based interpretive analysis involves inductive reasoning, guided and couched within a theoretical framework, from a concrete case situation to the social totality beyond the individual case. According to Stake (1994, p. 236), case studies can be qualitative and quantitative; however, he adds that the case study "is not a methodological choice, but a choice of object to be studied and what data can accrue from this study." Case studies are, therefore, defined by an interest in the individual cases, not by the methods of inquiry used. The case itself may be simple or complex; however, cases should be specific and bounded, as Stake contends that generalities do not qualify for study. Thus, Stake argues that a case is a unique functioning specific, it is an integrated bounded system, its behaviour is patterned, it exhibits consistency, and finally, sequentialities are prominent.

Three generic types of case studies are identified by Stake (1994). Given the research objective, the case study design chosen for this research is that of an instrumental case study. Hence, following Stake (1994), a case study of the institutional factors surrounding the establishment of a third level IT-based course aimed exclusively at the socially excluded in Irish Society is undertaken. Lincoln \& Guba (1985) argue that the primary instrument in qualitative research is human, i.e., the researcher. In the present study, this might pose certain problems in evaluating the study's objectivity present study, as the researcher was one of the central actors involved in the social drama surrounding the solutions to the problems here outlined. As such, the author was what Bødker \& Pedersen (1991) have termed a "cultural insider". Hence, as the academic charged with implementing a solution to the problem, and a member of the cross-institutional steering committee overseeing the initiative, he was intimate with several of the sub-universes of reality that comprised the overall institutional reality (see Berger \& Luckmann, 1966). Issues of 'objectivity' aside, this provided Lincoln \& Guba's (1985) 'human instrument' with valuable insights into the institutional cultures and climate, and greatly aided in the interpretation of the issues that surfaced in the case.

On the thorny issue of 'objectivity', King (1995) argues that qualitative studies attempt to describe and understand how people make sense of their world. In so doing, researchers are not required to strive for 'objectivity' and to distance themselves from social actors, as this would make interpretive research impossible to conduct. King also indicates that internal validity is of concern to both quantitative and qualitative researchers. For quantitative researchers, the focus of validity centres on questions of method; while 
for qualitative researchers, it centres on the validity of interpretations (see Madison, 1988). Hence, the researcher was sensitive to the need validate his interpretations and ensure the 'trustworthiness' of the research artifact (see Lincoln \& Guba, 1985). Because of the ex-post nature of the study, the research approach was inspired by that of Carl Jung (1993), whose reflections on his own life experiences constituted the rich autobiographical treatise Memories, Dreams, Reflections and informed his theories of the human psyche. This study's research approach was influenced by Jung's; accordingly, the case study narrative possesses an autobiographical dimension, with the researcher as narrator.

\section{Problems and Solutions in Exercising Corporate Social Responsibility}

This case report describes an Irish solution to a global problem - that is, how corporate social responsibility can be exercised jointly by both the public and private sectors in order to help bridge the 'digital divide'. Cork City, Ireland's southern capital, provides the social context for the unfolding narrative. Also described are the wider institutional forces at play in shaping third level education in Ireland. The problems that beset the socially disadvantaged and excluded in attaining third level qualifications are first delineated. The main corpus of this case report then describes a solution to these problems by reporting on the institutional structures which helped students from disadvantaged backgrounds cross the so-called 'digital divide'.

\section{The Problems: Social and Financial Status, Poor Education, and Sub-optimal Life Chances}

Although third level education is free in Ireland, it is still a daunting financial undertaking for students from working class communities, and almost impossible for those on the margins. This problem is exacerbated by Irish financial institutions, which are comparatively reluctant to fund students' education, especially if they are without means. Middle class children, on the other hand, encounter no such problems as their parents are well resourced and generally underwrite student loans or provide direct finance to their offspring. However, it must be noted that financial expenditure on education in the middle classes begins in kindergarten and continues throughout childhood as parents carefully select only the 'best' statesponsored public or private schools, while financing additional private tuition. All this is required because entry into third level education in Ireland is based on the results of the state-run Leaving Certificate examination. This examination is highly competitive, as students who receive the highest number of percentage points generally have their choice of third level courses. Students who receive private tuition and exam preparation over and above that given during normal school hours are therefore better prepared for this examination [SCE, CIGCA].

In recent years, IT-related courses have attracted a lot of interest, given graduates' earning potential, and therefore have high entry level requirements. This generally works against the socially excluded, whose academic performance lags far behind those of the better off in Irish society. However, the obstacles are not only financial, as children of the working and socially excluded classes generally do not receive the same level of motivational, emotional, or social support when it comes to higher education. Living in high-density Local Authority housing estates, children are exposed to the harsh realities of life, and find that the local secondary school provides no escape as the social and group norms, which cause so many of the problems on the housing estates also govern student attitudes. Poor nutrition, a paucity of parental guidance and support, negative peer-group influences, and all the other distractions of modern day life, militate against the scholastic development of the socially excluded. Take, for example, the observation by a secondary school principal from Cork City's working-class heartland ${ }^{1}$ that many bright boys from

\footnotetext{
${ }^{1}$ This area of Cork City provides this study with its social context and is the site of the initiative under review.
} 
such backgrounds enter first year of post-primary education full of promise, but by their third year, they are merely average in academic performance. The reasons he put forward for this are: (a) that most parents are unable to provide academic support beyond primary school level; (b) that many parents from socially excluded communities have literacy problems and are not numerate beyond basic math; and (c) that young males fall under the influence of peers who place little value on education. Of course, there are those that make it through despite the odds, but the key ingredient here appears to parental influence and support. Then there are those who by pure misfortune, e.g. teenage pregnancy, the death of a parent, accident or illness, are prevented from reaching their full emotional and intellectual potential.

Limited institutional support is available for those from disadvantaged backgrounds who fail to meet the normal educational criteria for entry into third level colleges. However, positions on state-funded access programs are restricted, and few places are available for those wishing to obtain an IT qualification from a third level institution. Those that do make it through, whether it is students who qualify for entry into ITrelated programs through the normal process, but who barely make the entry requirements, or those who qualify for state-funded access programs and are generally nowhere near the required competency levels, face even tougher hurdles. For example, a high proportion of such students who enroll for computer science-type courses usually flounder in the first year or so and drop out. This is due primarily to the difficulties they face in mathematics and science subjects because many of them have not adequately covered the required introductory material at secondary school level.

Taken together, the aforementioned problems result in a large proportion of highly intelligent young adults finding themselves in dead-end jobs with no prospects of advancement - that is underemployed, or unemployed, or as single parents with young children and no career. Then there are the disabled from disadvantaged backgrounds, who tend to suffer all of the above in greater degree.

\section{The Solution: Building Institutional Structures across the Digital Divide}

It's the first day of a new academic year at University College Cork (UCC). I'm standing in the cold morning air outside Ballyvolane Business Park in Cork's working class hinterland-colloquially referred to as the Northside. Perched on hills to the west are the local authority housing estates of Farranree, Gurranabraher, Churchfield, and Knocknaheeney, while in the valley below is old working class neighborhood of Blackpool. To the south and east of my present location are the sprawling Glen, Mayfield and Ballyvolane estates, while to the north are the public and private housing estates on Dublin Hill. Collectively, these working class enclaves constitute the Northside of Cork City-they are also home to the majority of the city's unemployed and socially disadvantaged. Many of the students in UCC's undergraduate diploma course in Applied Business Computing come from these estates, with the remainder living in similar neighborhoods on the city's Southside. Lest the reader be misled, University College Cork is not located on the Northside of the city, and certainly not at the present location; rather, the university campus is situated three miles away in the largely middleclass suburbs in the southwest of the city. However, in order to establish a presence on the Northside, and to help disadvantaged students cross the digital divide in terms of education and employment in the IT sector, UCC located a computer laboratory and academic offices at the Ballyvolane Business Park.

As I walk to unlock the door to the unit which houses this facility, I witness tangible signs of the social and economic divide in Irish society. Next to the perimeter fence on the embankment above me are halfdozen or so small caravans - these are the homes of 'Irish travelers,' who exist in third world conditions, without running water or any form of sanitation. A horse is tethered to the fence that runs the length of the compound, while sound of dogs barking and the voices of children preparing for school can be clearly heard-not your typical third level learning environment. The twenty-four students who will be arriving shortly to begin the second year of their undergraduate education will witness this scene on a daily basis. 
However, the inside of the facility lies in stark contrast to the scenes of destitution that greet them on their arrival. Brightly lit corridors, newly painted walls, highly polished floors, and a state-of-the-art computer laboratory provide tangible evidence to students of what lies on the other side of the digital divide. The following sections focus on the institutional factors which led to the development of the Diploma in Applied Business Computing and the establishment of this outreach learning centre in Cork's Northside.

\section{The Influence of Government Initiatives on Education Policy and Practice}

In the late 1990s, the Irish government promoted the need for a greater degree of social inclusion in Irish society. This aspiration found concrete expression in its various social and economic polices and in generous financial support for such initiatives [CIGCA, SCE, I]. Education was singled out for special attention here as it was widely recognized that the success of the Celtic Tiger economy was due in no small measure to the existence of a highly educated workforce: in contrast, literacy levels among many of the socially disadvantaged were among the lowest in Europe. One significant move by the Irish Government was to introduce free third level education for all citizens was the first step in this direction, although, for reasons outlined earlier, it made little difference to many of the socially excluded. Accordingly, the needs of a significant proportion of those from disadvantaged urban and rural areas continued to be badly served. In between lay a large body of literate, intelligent individuals who because of social circumstances and poor educational opportunities were unable to secure employment commensurate with their innate abilities. This was particularly true of those excluded from employment in IT.

As the Celtic Tiger economy began to grow in earnest during 1997 and 1998, the influx of new US multinationals, and the expansion of established organizations - national and international-increased the demand for workers with IT competencies at all levels - from technical support functions to senior software engineers. However, on the supply side, third level institutions were having difficulty keeping pace with existing demand, let alone servicing the forecasted increase. In line with government policy on social inclusion, the country's institutes of technology, which deliver certificate, diploma, and degree courses in a range of technology-related subjects, responded rapidly and instituted IT-related courses such as the Accelerated Technician Program. In Dublin, Ireland's capital, the demand for IT skills was particularly acute. In response to this, an industry-led initiative saw government departments, community groups, Vocational Education Committee (VEC) colleges, and the state training agency FÁS, collaborate in what become know as the Fastrack to IT (FIT) initiative. The purpose of these programs was to provide the socially excluded with basic IT skills so that they could feed the growing demands of industry.

One group of institutions failed to exercise social responsibility in this area-Ireland's universities. Some background information will serve illustrate why this occurred. Ireland possesses a three-tier third level education system. The longest and most established entities here are the national universities ${ }^{2}$, the largest of which date from the $19^{\text {th }}$ century. The Introduction of free secondary-level education in the 1960 s led to the institution of VEC colleges and regional technical colleges (RTCs, now institutes of technology, such as Cork Institute of Technology, CIT). The purpose of these institutions was to service the further education needs of the growing numbers of second-level students from both working and agrarian classes so that they could participate in the economy in non-professional administrative, highly-skilled craft and technical capacities. The universities continued to service the needs of the middle and professional classes, and also the offspring of wealthy farmers in the agrarian community. Students from the lower classes found their way into university, but they were the exception, rather than the rule. It came as no

\footnotetext{
2 National University of Ireland, Dublin; National University of Ireland, Cork; National University of Ireland, Galway; National University of Ireland, Maynooth; The University of Dublin, Trinity College; Dublin City University; University of Limerick.
} 
surprise, then, that the universities were slow to change [I, CIGCA, SCE]. Change when it did occur, came at the behest of the Higher Education Authority (HEA), the government sponsored body that acts in an advisory capacity to the Irish third level education sector. The HEA acts in an advisory capacity to the universities and is responsible for administering government funding to them. It was, therefore, well placed to communicate the wishes of the government of the day to the universities so that they would exercise some social responsibility, particularly in providing courses for the socially excluded. The HEA could not demand that universities deliver such courses; it could only exercise moral suasion and the notso-insignificant carrot of funding. While the HEA influenced the universities directly, public representatives and government ministers exercised indirect influence. Hence, a combination of influences were brought to bear in order bring the universities into line with the spirit-of-the-times [SCE]. Leading the horse to water was one task, getting it to drink was entirely another issue - the following section explains why.

\section{Institutional Horse Trading at UCC}

This section illustrates that the influence of the HEA and the representations of major political players were not enough to have UCC exercise of social responsibility. The personal commitment of academic visionaries who held influential roles in this institution was also required.

The first time I heard of UCC's intention to establish a diploma in IT targeted at the underprivileged was in September of 1998 at meeting of IS academic staff in the Department of Accounting, Finance and Information Systems. At the time, I was on leave of absence from my then employer, Telecom Éireann (now eircom), the state telephone company, and held a contract position as a college lecturer in MIS. The acting head of department, who held a chair in MIS and was a member of the HEA's governing body, declared his intention to support the establishment of a diploma program aimed at the socially disadvantaged in the Northside of Cork City. He therefore asked interested staff members to form a committee to devise a draft proposal and course curriculum. As a Northsider from a working-class background, I was well placed to understand and be sensitive to the needs of the constituency of interest. I was not surprised then when I was charged me with overall responsibility for getting the project off the ground.

As this type of initiative was the first of its kind for a mainstream academic department, it was decided that it would be administered by the university's Centre for Adult Continuing Education, which was coordinating several community-based outreach programs aimed at adults. The Cork City Partnership Ltd., which was a government sponsored community body charged with facilitating the long term unemployed to return to work, was also to act in an advisory capacity in identifying potential students. Within a week of that meeting, the committee presented a draft proposal to the Director of the Centre for Adult Continuing Education for the consideration the Faculty of Arts at its next meeting. Briefly, this document set out the rationale for the program, it identified the target constituency, the participating institutions, the curriculum, and the length of the course, which was initially set at 18 months or three academic semesters. The document also proposed a start date of January 1999.

Problems arose early, as what was a political imperative for government became a political football for academics. The overt battle was waged around the title chosen for the course, the covert battle centered on in-house political disagreements, which was a continuation of ongoing academic conflict by other means [CIGCA, OI, I, SCP]. When the proposal was presented at the Arts Faculty meeting in November of 1998, an opinion was expresses that the title 'Diploma in Applied Computer Programming' was more in keeping with computer science-type courses and not those offered by information systems. In any event, a revised proposal was put before faculty in May of the following year with the title changed to 'Diploma in Applied Business Computing.'

By the autumn of 1999, matters had been finally resolved. However, it was evident that the diploma course would not have become a reality without the commitment of the two senior academics involved in 
promoting it - the Professor of MIS and the Director of the Centre for Adult Continuing Education. Significantly, both were Cork born and bred, both came from working class backgrounds - one a Northsider, the other a Southsider — consequently, neither possessed the aloof attitudes associated with dyed-in-thewool academics. This goes some way in explaining their commitment to the project and the practical approach they adopted in getting it off the ground [SCP, CIGCA]. Given the prevailing attitude among some academics at the university, it is a debatable whether this project would have gone ahead, pressure from the HEA notwithstanding. In any event, the steering committee charged with implementing the project met for the first time in January of 2000, one full year after the original date for commencement.

\section{Meanwhile, Back at the Ranch}

In 1999, the Minister for Education in the Irish Government happened to be a Corkman. Politics being what it is, a pressure group was formed to canvass for a 'Northside Campus' that would serve the third level education needs of adults and school-leavers from the area. Drawing on experiences in other cities, where it was observed that business parks and industry startups were established in the wake of new third level institutions, it was hoped that the presence of such a campus in the Northside would help reduce unemployment levels in what was a regional black spot. It was also hoped that some measure of balance would be introduced in access to third level education [CIGCA, SCE]. A little geography lesson will help illuminate the issue.

The river Lee flows through the centre of Cork from west to east and divides the city neatly in two. It is no accident of geography that Cork's hilly Northside is home to the most the socially disadvantaged areas of the city, while the Southside is chiefly populated by the middle classes-local authority planners from middleclass backgrounds were chiefly responsible for this state of affairs. This class-driven, social and geographic divide is reflected in an economic gulf that sees the location of Cork's major business and technology parks concentrated in the Southside of the city-indeed, over the past 40 years the major centres of employment were all based south of the river Lee. It is also no accident of geography that Cork's two third level institutions (University College Cork and Cork Institute of Technology) and vocational education centres (such as the Cork College of Commerce) were situated on the Southside. Hence, local community leaders, politicians, clergy and academics were keen to see a Northside-based third level institution $[\mathrm{SCE}]$.

This project became known as the 'Northside Initiative.' With the support of the then Minister for Education, a committee was formed with members drawn from UCC, CIT, Cork Corporation, Cork City Partnership Ltd., and representatives from local commercial bodies. The committee decided that the best approach would be to establish a 'Northside Campus' that would be run jointly by UCC and CIT [I]. The new campus was planned for the Blackpool area, which is situated in the heart of the Northside of Cork City. By 2000, some $£ 10$ million pounds (12,250 Euros) of capital funding had promised from the Irish Government, with a pledge for continued support. It is significant, then, that this announcement was made in Blackpool by the Taoiseach (the Irish Prime Minister) when the Cabinet held one of its regular meetings in Cork. This was to have a considerable impact on the progress and direction of the diploma project, as the following section illustrates [SCE].

\section{Institutional Webs around the Diploma in Applied Business Computing}

The executive steering committee charged with implementing the Diploma in Applied Business Computing first met in January of 2000. The committee consisted of four members of the Cork City Partnership and four academics and an administrator from UCC. Of the many issues discussed at this and subsequent meetings, the most important were funding and where to locate and deliver the diploma course. The HEA had allocated $£ 75,000$ to cover setup costs. However, back-of-the-envelope estimates made at the initial meeting suggested that this might be insufficient if the diploma was to be situated off-campus, which was 
the preferred option for several reasons. The decision to locate off-campus was an important one, as it had major short and long-term ramifications, as will be seen.

It was clear from the outset that while the committee would make all the decisions regarding the new course, I would have to carry them out. Just how much that would entail in terms of time and energy, I wouldn't fully realize until October of that year. My first task was to revisit the draft proposal, in order to examine the proposed curriculum and find the academic staff to deliver it. The first thing that dawned on me was that the proposed course outlines were impractical, given the then timescale of 18 months and the target group involved. I also realized that the academic content was, perhaps, overly ambitious and too demanding for the students. I therefore redesigned the course so that academic rigor would be balanced with practical relevance of the subject matter for both students and prospective employers. The core modules now consisted of courses in the following subject areas: IT architectures (that is, IT fundamentals, Windows 2000 Professional and Server client/server operating systems and internetworking); Oracle database design and development; Visual Basic programming; and the development of multimedia systems for the Internet (using Macromedia's Dreamweaver and Director, Adobe's Photoshop, HTML, and JavaScript programming). I was also of the opinion that graduates' employment prospects would be enhanced if I integrated Microsoft certification material into the curriculum.

The second issue which arose at this time was that due to the increased demand for IT-related courses in UCC, I would not have the necessary numbers of academic staff to deliver the course. It then occurred to me that if the IT industry were going to benefit from this initiative, they might be prepared to provide IT professionals pro bono to teach into the course. This was the second major decision to affect the course content and quality of the learning experience for students.

In February and March of 2000, I set about contacting various players in the IT industry who I felt might wish to exercise corporate social responsibility by sponsoring the program. Another issue was that due to the limited financial support provided to set up the course, I would need to obtain funding and/or support in the provision of training materials. Accordingly, I made direct and indirect contact with several national and multinational companies in the IT sector. Many e-mails, lengthy international telephone calls, and several business lunches later, I had succeeded in obtaining significant levels of support. Consequently, Microsoft Corporation (Ireland) supplied courseware from the IT Architectures and Visual Programming modules gratis for the students (worth and estimated $£ 6,000$ or more, at the time). Microsoft also put me in contact with Cara Training, the largest of the Irish companies delivering Microsoft certified training for the IT industry. Cara acted as a channel for Microsoft and handled the delivery of the courseware. More significantly, however, Cara agreed to participate in delivering the IT Architectures module. They also provided such services as setting up the laboratory clients and laboratory server. Oracle Corporation provided two full copies of their enterprise database platform Oracle 8i, in addition to permission to copy and distribute Oracle Personal Edition to students: they also undertook to provide course ware, if required. I also approached Motorola and $\mathrm{EMC}^{2}$, both of whom have a significant presence in Cork. EMC $^{2}$ declined my invitation to participate, while Motorola's head of operations indicated that he would provide up to four IT professionals to teach into the course. I also approached my former employer, eircom, Ireland's largest telecommunications operator. As with Motorola, they were willing to provide me with competent IT professionals to help deliver the program. Finally, FÁS, the national training agency, offered an experienced MCSE qualified trainer. By May of 2000, I was confident that I would have enough lecturers/tutors to run the course [SCE]. The fact that I had structured the core elements of the course around IT architectures, programming, database, and web-development helped greatly in 'selling' the program and obtaining the level of support I required.

From January to May of 2000, the steering committee grappled with three major issues: Where to locate the course - on-campus or off; how to acquire sufficient funding for setting up the program; and whether to restrict the student intake to those resident in the Northside or broaden it to the city and suburbs. While the $£ 75,000$ would be theoretically sufficient to set up the course on-campus, there would be a problem 
with accommodation, as the university was suffering capacity constraints. The pros and cons of having the students on-campus were also debated at length. In the final analysis, events in the wider institutional environment-i.e. the proposal to set up a 'Northside Campus' - had the committee opt for a location in or close to the Blackpool area [SCE, OI, CIGCA]. Between March and May, several potential sites were evaluated. The most suitable were Ballyvolane Business Park and St. Finbarr's Secondary School at Farranferris College, Blackpool. The former accommodation was being offered by Cork Urban Enterprises at a significantly discounted rent, and was therefore attractive. The latter was being touted as a possible location for the 'Northside Campus,' as the Catholic Bishop of Cork had offered land in order to site the campus; hence, it would have been ideal as a launch pad for the larger initiative. However, the principal had other plans for the available space in the school and the option of erecting a prefabricated building was explored. In any event, it was decided to construct a computer laboratory, office space, and kitchen/dining area in the unit at Ballyvolane Business Park. Funding now became the critical issue; it was fortunate then that a link was made, however tenuous, with the politically sensitive 'Northside Campus'.

When the planned diploma program came to the notice of the committee responsible for driving the 'Northside Initiative' it was suggested that Cork Institute of Technology should become involved and that the diploma should act as a pilot project of sorts for the 'Northside Campus.' CIT's experience in setting up their Educational Opportunities Department with its adult-centered programs was viewed as being a positive asset to the diploma program. The steering committee was therefore enlarged to include CIT's Registrar, academic staff from the Mathematics and Computing Department and the Educational Opportunities Department [I, OI, SCP]. The inclusion of CIT also brought with it lecturers in Multimedia and Web-development to help deliver the program. The existence of the diploma was now seen as being vital for introduction of the 'Northside Campus,' and its enhanced status brought with it financial help from an unexpected source. An 'anonymous donor' had pledged $£ 100,000$ to help establish the learning centre at Ballyvolane. Some $£ 175,000$ capital was now in place-nevertheless, this was regarded as being insufficient [SCE].

Further funds from the HEA would not be forthcoming, and both CIT and UCC were not a position to provide capital funds. A chance conversation had a senior official from the government Department of Social Community and Family Affairs call me with an offer of support: this materialized into $£ 40,000$ to equip and network the computer laboratory [SCE, OI, CIGCA]. All that needed to done now was build the facility and, of course, recruit students to undertake the not insignificant task of spending two years of their lives in full-time education. The third issue mentioned previously had been resolved for the committee, as the HEA had indicated that restricting the selection of students to one area of the city was undesirable [SCE]. Students from socially excluded backgrounds in all areas of the city were therefore considered eligible for inclusion to the course. As expected, the majority of the students came from the city's Northside.

\section{Build IT and They Will Come?}

While the overall decisions on where to locate the learning facility were made at committee level, it fell to me to implement them; hence, I had to find a builder who would do the job at the cheapest cost and in the shortest time possible. It was now May 2000, with a planned starting date of the first week in October. In order to comply with institutional protocol in such matters and provide an audit trail for UCC and the HEA, a formal tendering process had to be entered into. To do this, a set of plans had to be developed. While I drew up the outline plans myself, I passed the task of formally drafting the plans to UCC's planning office. I soon realized that if official protocol was to be followed to the letter, we'd be holding classes in the parking lot of Ballyvolane Business Park come October. While shortcuts were avoided, I depended on goodwill in great measure to accelerate the process. Finding a builder in Ireland's overheated economy in 2000 was difficult; locating one that would do the job on time and for a reasonable price was an almost impossible task. In any event, I was lucky to come across just such an individual, and the facil- 
ity was completed in August. In order to ensure that the building conformed to building regulations and planning standards, I had to acquire the services of a civil engineer who would oversee the construction, while I dealt with day-to-day project issues. Along the way, unanticipated modifications had to be made to comply with various fire safety and building regulations and with health and safety guidelines; these added to the overall cost of the infrastructure, but the project remained within budget. That this happened was something of a minor miracle; however, the nature of the project had people commit to it in surprising ways and this helped enormously [SCP, I, CIGOA, SCE].

\section{The Recruitment Drive and the Early Days}

By the end of May 2000, the advertising drive had begun. Airtime had been booked on local radio stations so that a member of the committee could provide information on the course. The program would also receive regular mention by local radio DJs. Information leaflets and posters were also published and distributed to all public offices in the city, especially post offices where the socially disadvantaged received their welfare payments and in the offices of the Department of Community and Family Affairs. This department had responsibility for the unemployed, and therefore undertook to mail shoot unemployed people and others receiving social welfare payments in order to inform them of this opportunity to come off welfare and find worthwhile and well-paid employment. Local Employment Service (LES) and Department of Community and Family Affairs office staff were briefed about the course so that they could provide advice and details not on the leaflet and help prospective students fill out their application forms which were available at LES offices.

Early on, the executive steering committee realized that standard financial support for students, i.e. social welfare payments, lone parent allowances, disability payments, Back to Education and other grants, might not be sufficient to support certain students, particularly lone parents. The Cork Community Partnership Ltd. therefore allocated $£ 10,000$ (12,270 Euro) of its funding for students' childcare expenses, where appropriate. However, while financial support was important, so were other non-financial support mechanisms, such as counseling and advice. Three social workers from the Cork City Partnership and a counseling psychologist from CIT would hold clinics on-site when the course was established [I]. Much of this information was made available to applicants beforehand so that they could make an informed choice to participate.

The closing date for applications was Monday the $4^{\text {th }}$ of September 2000. Next came the task of student selection. In researching similar initiatives, notably the FIT project in Dublin, I had identified that student selection would be critical given the intensive nature of the program and the possibility of high levels of student drop out. I therefore decided to hold aptitude tests that would focus primarily on technical competences and related aptitudes. Operating within a tight budget, I secured the services of two occupational psychologists from Dublin who were involved in the FIT project and who agreed to perform the tests at cost. The aptitude tests were delivered over two days at the university to over 70 successful applicants, just under half the total that had applied. I had agreed a set of criteria with staff from the LES so that they could perform the pre-selection of applicants in order to eliminate those ineligible for positions on the course.

Sixty students were called for interview on the basis of their performance in the aptitude tests. The interviews were held in UCC over two days and only those candidates who met predetermined criteria and whom the interview panels felt would be likely to complete the course were selected. As three separate interview panels were involved, a common grading scheme was employed to help rank applicants. The panel chairpersons then met in order to select twenty-five prospective students. A problem arose, however, as the number of individuals found eligible numbered over thirty. Some hard choices had to be made; however, in the spirit of the moment, three extra places were created for the most deserving candidates. The selection panel members were please with this development as they had their own 'favorites' or 'hard cases' and these could now be accommodated. In any event, the final selection had an unintended 
'politically correct' outcome as fourteen of the students were male and fourteen female. Of these, five were disabled, nine were lone parents, three were underemployed, and 11 were long-term unemployed.

On Monday $9^{\text {th }}$ of October 2000, twenty-eight students attended their fist day of a five-day induction course at the computer laboratory in Ballyvolane Business Park. On entering this facility, students were confronted with fifty-six cardboard boxes, which contained the workstations and VDUs they would use over the next two years. The first task I charged them with was to unpack their computers, connect the various components using the cables provided, power them up and install software. I then had students configure their machines as clients in a Windows NT domain. All this was performed under the guidance of myself and three other lecturers-one from UCC, the MCSE instructor from FÁS, and the IT manager from Cara Training. A system administrator had not been provided for the laboratory network due to

\begin{tabular}{|l|l|}
\hline Type of Commitment & Description \\
\hline $\begin{array}{l}\text { Commitments enforced by } \\
\text { uniquely organizational im- } \\
\text { peratives. }\end{array}$ & $\begin{array}{l}\text { 'Organizational imperatives' observed in the case centered on the establishment } \\
\text { of the Diploma in Applied Business Computing for socially disadvantaged stu- } \\
\text { dents and the 'Northside Campus' to meet the needs of the wider constituency } \\
\text { of the socially excluded in Cork's predominantly working class Northside. }\end{array}$ \\
\hline $\begin{array}{l}\text { Commitments enforced by } \\
\text { the social character of the } \\
\text { personnel. }\end{array}$ & $\begin{array}{l}\text { Although the majority of social actors could have been described as predomi- } \\
\text { nantly middleclass, the working class backgrounds of key actors, and the pro- } \\
\text { fessional academic and social nature of the individuals involved, ensured that } \\
\text { the special needs of the target constituency were met and obstacles negotiated. }\end{array}$ \\
\hline $\begin{array}{l}\text { Commitments enforced by } \\
\text { institutionalization. }\end{array}$ & $\begin{array}{l}\text { The various goals, policies and procedures of social actors involved in setting } \\
\text { up the program achieved an established, value-impregnated status. Commitment } \\
\text { to newly-established institutionalized norms and practices (from the approach } \\
\text { taken in implementing the program to the approach adopted by lecturers in de- } \\
\text { livering it) were accomplished that transcended those of the wider institutional } \\
\text { contexts such as those within social actors' institutions of origin. }\end{array}$ \\
\hline $\begin{array}{l}\text { Commitments enforced by } \\
\text { the social and cultural envi- } \\
\text { ronment. }\end{array}$ & $\begin{array}{l}\text { The organizational policies and outcomes associated with the institution of the } \\
\text { diploma were seen to be influenced and shaped by a multitude of actors in the } \\
\text { external social and cultural environment. }\end{array}$ \\
\hline $\begin{array}{l}\text { Commitments enforced by } \\
\text { the centers of interest gener- } \\
\text { ated in the course of action. }\end{array}$ & $\begin{array}{l}\text { Whereas decentralization and delegation of decision making to the executive } \\
\text { steering committee and individuals such as the course coordinator, support staff } \\
\text { etc., none were seen to be influenced by the tangential informal goals of such } \\
\text { individuals or sectional interests. Such commitments were generally well- } \\
\text { aligned with those of the 'organization.' }\end{array}$ \\
\hline
\end{tabular}

\section{Table 2: Commitment and the Social Construction of institutional Reality} (adapted from Selznick, 1949)

budgetary limitations; hence, students would have to learn to administer their client workstations under my direction. At the time, I believed throwing students in at the deep end would give them a sense of achievement. This strategy proved correct as students' levels of enthusiasm and motivation were heightened from the outset. They were in the right frame of mind to start the induction course, which would help orient students and prepare them for following two years of intensive study [I].

Hence, the purpose of the induction course was to provide the students with information on the various support structures that were in place to help and advise them. It was also an opportunity to introduce them to the support staff, as they had already met academic staff prior to registering for the course in UCC. The support staff consisted of three social workers from the Cork City Partnership Ltd. and a counseling psychologist from Cork Institute of Technology. Support staff attended at fixed times each day to help students with issues of a personal nature that might negatively influence their academic performance or 
threaten their commitment to continue with the course. From the outset, students were quick to settle into the routine of academic life and made significant progress on all fronts as the academic year progressed. One problem arose, however. Under Department of Education regulations, third level student grants are only awarded for full-time courses of two academic years or more in duration. The planned 18-month timescale of three academic periods was therefore extended to four academic periods to fall within the regulations governing student grants [I, OI]. This was fortunate in many ways, as the course content proved quite challenging and students required the extra time to develop their competencies in all subject areas.

The highlight of the first year came with the official opening in February, which was performed by the Taoiseach, Mr. Bertie Ahern. Other senior members of government attended, as did church leaders and the presidents of Cork's third level institutions-UCC and CIT. The national media were present to record what was a significant event for the students and the various institutions and individuals who participated in helping bridge the digital divide. The approach taken was a lauded as a model of future ventures; in recognition of its success, the Taoiseach announced his commitment to the wider ambition of a 'Northside Campus' [SCE, CIGOA].

\section{Discussion and Conclusions}

At the time of writing, the diploma students are looking forward the completion of the course and the attainment of a diploma in IT. The planning, implementation, and delivery of the program were undoubtedly an enormous success. A question therefore begs: What were the institutional influences governing the success of this program and how were they manifested?

The answer to this question is contained in the case report; nevertheless, a short discursive analysis will highlight the salient issues. It is clear that the executive steering committee which was formed to establish and help implement the diploma course was merely a 'technical instrument' aimed at implementing the HEA's goal of establishing a third level IT-based course for the socially excluded. However, as 'social needs and pressures' became manifest in the commitments of the social actors participating or involved in the immediate challenge of implementing the HEA's objective, and in the secondary goal of obtaining government support for a 'Northside Campus', a web of commitments evolved and acted to support the achievement of both aims [I, CIGOA, OI]. Commitment was therefore the institutional 'glue' that acted to bind social actors to the fulfillment of 'organizational' imperatives and helped shape institutional context and process to achieve desired ends. Table 1 presents an analysis of the commitments observed in this study. Evidence of this socially constructed web of commitments has been adduced in the case report and flagged using the notation introduced in Section 2.

But what of the students? As course coordinator, I have seen each and every one of them blossom in unexpected ways. Four of the original twenty-eight have dropped out, each for personal reasons-but not before they visited the other side of the digital divide. In the run up to the final examinations, I can see that three more are experiencing difficulties. However, as for the remainder, they can see a bright future, despite the current downturn in demand for IT workers. Many have PCs at home now and have sophisticated applications such as Oracle, Visual Basic, and Dreamweaver installed (and know how to use them). All illustrate high levels of motivation and enthusiasm in their attitude toward the course, although some have yet to shake off some old bad habits, while others struggle because of personal circumstances.

In conclusion, the diploma course has been an unqualified success and has achieved its objectives and those of the policy makers who instituted it. However, what made it so was the commitment of concerned stakeholders, from members of the executive steering committee who developed and implemented the course, to the lecturers who delivered it, and the students who participated in it. While policy makers and social commentators utter many inspiring words concerning social inclusion, it takes more than wellintention utterances and government funding to transport the socially excluded to the other side of the 
Bridging the Digital Divide

digital divide. This study has illustrated just what is required, it should, therefore, help deepen the understanding of policymakers and educators alike.

\section{References}

Berger, P. \& Luckmann, T. (1967). The Social Construction Of Reality-A Treatise in the Sociology of Knowledge. Doubleday and Company Inc., Garden City, NY.

Bødker, K. \& Pedersen, J. (1991). Workplace Cultures: looking at artifacts, symbols and practices. In J. Greenbaum \& M. King (Eds.), Design at Work: Collaborative Design of Computer Systems, Lawrence Erlbaum Associates, 121-136.

Bruner, J. (1990). Acts of Meaning. Harvard University Press, Cambridge, MA.

DiMaggio, P.J. \& Powell, W.W. (1991). The Iron Cage Revisited: Institutional Isomorphism and Collective Rationality in Organizational Fields. In W.W. Powell \& P.J. DiMaggio (Eds.), The New Institutionalism in Organizational Analysis, London: University of Chicago Press.

King, N. (1995). The Qualitative Research Interview. In Cassell, C. \& Symon, G. Qualitative Methods in Organizational Research, Sage Publications, London, 208-229.

Jung, C.G. (1993). Memories, Dreams, Reflections. Fontana, London.

Madison, G. B. (1988). The Hermeneutics of Postmodernity: Figures and Themes. Indiana University Press, Bloomfield, IND.

Orlikowski, W.J. \& Baroudi, J.J. (1991). Studying information technology in organisations: research approaches and assumptions. Information Systems Research, 2, 10-28.

Scott, W.R. (1995). Institutions and Organizations. Sage Publications Ltd., Thousand Oaks, CA.

Selznick, P. (1949). TVA and the Grass Roots. University of California Press: Berkley and Los Angeles, CA.

Selznick, P. (1957). Leadership in Administration. A Sociological Interpretation. Harper and Row, NY.

Stake, R.E. (1994). Case Studies. In N. K. Denzin and Y. S. Lincoln (Eds.), Handbook of Qualitative Research. Sage Publications, CA, pp. 236-247.

Walsham, G. \& Waema, T. (1994). Information Systems Strategy and Implementation: A Case Study of a Building Society. ACM Transactions on Information Systems 12(2), 150-173.

Winograd T. \& Flores, F. (1986). Understanding Computers and Cognition: A New Foundation for Design. Ablex Publishing Corporation, Norwood, NJ.

\section{Biography}

Tom Butler is a College Lecturer in Management Information Systems at University College Cork (UCC). Formally a telecommunications engineer with eircom, Tom has a wealth of practical experience in the IT industry. He holds an MSc in Information Systems from the National University of Ireland and has completed his $\mathrm{PhD}$ at UCC. His research interests encompass the design, development, and implementation of IS and include such topics as the use of CASE, user participation, organisational change, and the role of IT competencies in the development of IT infrastructures. He is also interested in the application of interpretive methods for research in IS. His studies has been published and presented at a number of international conferences and he has several book and journal publications.. 